\title{
Kinetics Study of the Hydrodeoxygenation of Xylitol over a $\mathrm{ReO}-\mathrm{Pd} / \mathrm{CeO}_{2}$ Catalyst
}

\author{
Blake MacQueen ${ }^{1}{ }^{\circledR}$, Michael Royko ${ }^{1}$, Bradie S. Crandall ${ }^{1}$, Andreas Heyden ${ }^{1} \oplus$, Yomaira J. Pagán-Torres ${ }^{2} \mathbb{D}$ \\ and Jochen Lauterbach $1, * \mathbb{D}$ \\ 1 Department of Chemical Engineering, University of South Carolina, 541 Main St., Columbia, SC 29208, USA; \\ blakehm@email.sc.edu (B.M.); roykom@email.sc.edu (M.R.); bradie@email.sc.edu (B.S.C.); \\ heyden@cec.sc.edu (A.H.) \\ 2 Department of Chemical Engineering, University of Puerto Rico-Mayaguez Campus, \\ Mayaguez, Puerto Rico 00681-9000, USA; yomairaj.pagan@upr.edu \\ * Correspondence: lauteraj@cec.sc.edu
}

Citation: MacQueen, B.; Royko, M.; Crandall, B.S.; Heyden, A.; Pagán-Torres, Y.J.; Lauterbach, J. Kinetics Study of the Hydrodeoxygenation of Xylitol over a $\mathrm{ReO}-\mathrm{Pd} / \mathrm{CeO}_{2}$ Catalyst. Catalysts 2021, 11, 108. https://doi.org/10.3390/ catal11010108

Received: 9 December 2020 Accepted: 11 January 2021 Published: 14 January 2021

Publisher's Note: MDPI stays neutral with regard to jurisdictional clai$\mathrm{ms}$ in published maps and institutional affiliations.

Copyright: (C) 2021 by the authors. Licensee MDPI, Basel, Switzerland. This article is an open access article distributed under the terms and conditions of the Creative Commons Attribution (CC BY) license (https:// creativecommons.org/licenses/by/ $4.0 /)$.

\begin{abstract}
In this study, we elucidate the reaction kinetics for the simultaneous hydrodeoxygenation of xylitol to 1,2-dideoxypentitol and 1,2,5-pentanetriol over a $\mathrm{ReO}_{x}-\mathrm{Pd} / \mathrm{CeO}_{2}$ (2.0 weight\% $\mathrm{Re}$, 0.30 weight $\% \mathrm{Pd}$ ) catalyst. The reaction was determined to be a zero-order reaction with respect to xylitol. The activation energy was elucidated through an Arrhenius relationship as well as nonArrhenius kinetics. The Arrhenius relationship was investigated at $150-170{ }^{\circ} \mathrm{C}$ and a constant $\mathrm{H}_{2}$ pressure of 10 bar resulting in an activation energy of $48.7 \pm 10.5 \mathrm{~kJ} / \mathrm{mol}$. The investigation of non-Arrhenius kinetics was conducted at $120-170{ }^{\circ} \mathrm{C}$ and a sub-Arrhenius relation was elucidated with activation energy being dependent on temperature, and ranging from $10.2-51.8 \mathrm{~kJ} / \mathrm{mol}$ in the temperature range investigated. Internal and external mass transfer were investigated through evaluating the Weisz-Prater criterion and the effect of varying stirring rate on the reaction rate, respectively. There were no internal or external mass transfer limitations present in the reaction.
\end{abstract}

Keywords: heterogeneous catalysis; kinetics; hydrodeoxygenation; xylitol; Rhenium; biomass upgrading; sugar alcohol

\section{Introduction}

Lignocellulosic biomass can be utilized to produce various sugars, which can further be upgraded to value-added fuels and chemicals by removing the hydroxyl groups [1-4]. Xylan, which can be derived from hemicellulose, can be further upgraded to sugar alcohols such as xylitol. Xylitol is a five-carbon sugar alcohol that can be produced through the hydrolysis of xylan to xylose, followed by fermentation of xylose to xylitol [5-8]. Xylitol contains five vicinal hydroxyl groups, which can be removed to upgrade xylitol to value-added chemicals. An effective way to remove hydroxyl groups from xylitol is simultaneous hydrodeoxygenation (S-HDO) [9-11]. The S-HDO of xylitol produces 1,2-dideoxypentitol and 1,2,5-pentanetriol if one pair of vicinal hydroxyl groups is removed or 1-pentanol and 3-pentanol if two pairs of hydroxyl groups are removed. 1,2-dideoxypentitol and 1,2,5-pentanetriol are value-added chemical building blocks that are between 300 to 5000 times more valuable than xylitol [9]. 1,2,5-pentanetriol can be converted to tetrahydrofurfuryl alcohol and 3-hydroxytetrahydropyran through dehydration [12,13]. 1,2,5-pentanetriol has also been produced from D-ribose [14], but xylitol offers a potentially economic path for 1,2,5-pentanetriol and 1,2-dideoxypentitiol production via S-HDO due to the current large-scale production of xylitol. S-HDO consists of two steps, a deoxydehydration (DODH) step, followed by a hydrogenation step. The DODH removes two vicinal hydroxyl groups and forms a double bond between the carbons previously containing the hydroxyl groups. The hydrogenation then occurs, and the double bond is hydrogenated to a single bond. The state-of-the-art catalyst for this reaction is a 
$\mathrm{ReO}_{\mathrm{x}}-\mathrm{Pd} / \mathrm{CeO}_{2}$ catalyst, which utilizes the Re to catalyze the DODH step $[10,11,15]$ and the $\mathrm{Pd}$ to facilitate hydrogen dissociation on the surface of the catalyst to catalyze the hydrogenation step [15]. The dissociation of hydrogen, catalyzed by the Pd, also allows for the $\mathrm{ReO}_{x}$ to reduce during the proposed reaction mechanisms $[10,15] . \mathrm{ReO}-\mathrm{Pd} / \mathrm{CeO}_{2}$ has been shown to be over $99 \%$ selective to the S-HDO products while achieving high rates of conversion [10,11]. Active metals including Re, $\mathrm{W}, \mathrm{Mo}, \mathrm{Cr}, \mathrm{Nb}, \mathrm{Mn}$, and $\mathrm{V}$, additives including $\mathrm{Co}, \mathrm{Ni}, \mathrm{Cu}, \mathrm{Ru}, \mathrm{Rh}, \mathrm{Pd}$, $\mathrm{Ir}$, and $\mathrm{Pt}$, and supports including $\mathrm{CeO}_{2}, \mathrm{SiO}_{2}, \mathrm{C}$, activated carbon, $\mathrm{Al}_{2} \mathrm{O}_{3}, \mathrm{ZrO}_{2}, \mathrm{TiO}_{2}, \mathrm{MgO}, \mathrm{CaO}, \mathrm{La}_{2} \mathrm{O}_{3}$, and $\mathrm{Y}_{2} \mathrm{O}_{3}$ were previously screened in the literature [10,11]. Of the materials screened, the combination of $\mathrm{ReO}_{\mathrm{x}}-\mathrm{Pd} / \mathrm{CeO}_{2}$ had the highest selectivity and conversion for the S-HDO reaction. The reaction schematic for xylitol S-HDO is shown in Figure 1.

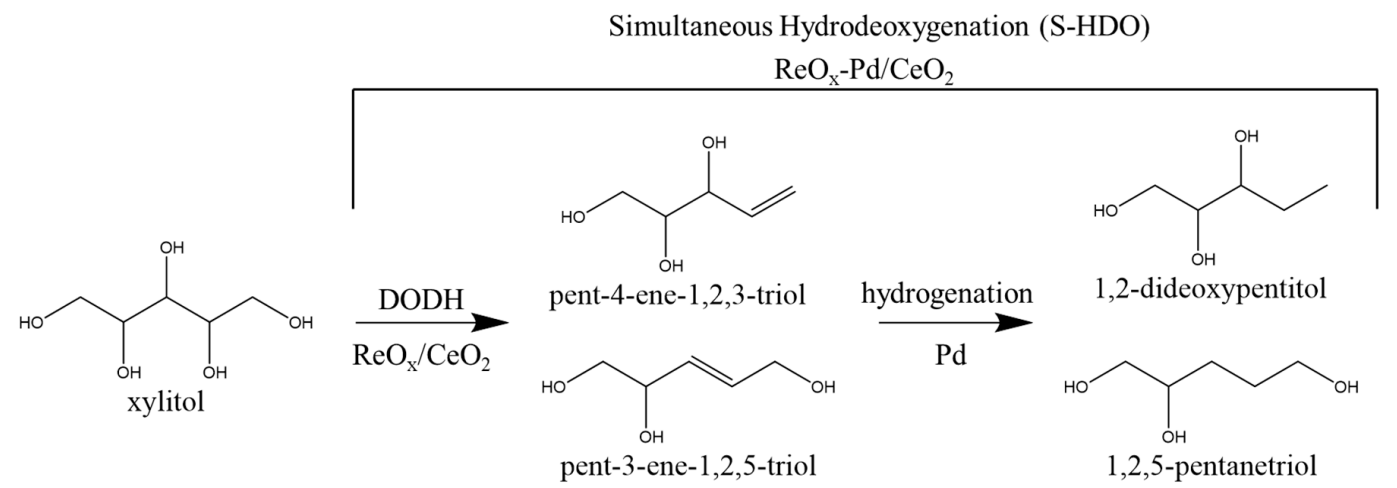

Figure 1. Reaction schematic of xylitol simultaneous hydrodeoxygenation.

The $\mathrm{ReO}_{x}-\mathrm{Pd} / \mathrm{CeO}_{2}$ has been previously optimized [11], and reaction mechanisms for S-HDO $[11,15]$ have been proposed. However, the general kinetics of xylitol S-HDO has not been investigated. DODH has been investigated on a variety of similar substrates and utilizing Re [11,15-17] based and Mo [18] based catalysts in the literature, and a variety of activation energies has been reported. Table 1 shows the various reactions, activation energies, and method of determination for similar DODH reactions as reported in the literature. Density Functional Theory (DFT) calculations have been the predominant method for activation energy prediction, with predictions ranging from $65-153 \mathrm{~kJ} / \mathrm{mol}$ depending on the catalyst and substrate. However, recently Cao et al. [17] performed both DFT and experimental calculations for the DODH of methyl $\alpha$-L-rhamnopyranoside and methyl $\alpha$-L-fucopyranoside over a $\mathrm{ReO}_{x}-\mathrm{Pd} / \mathrm{CeO}_{2}$ catalyst. They showed that the predicted and observed activation energies were close and were on the lower end of the activation energies proposed in the literature. The experimental determination of activation energy showed that similar reactants can have much lower activation energies and that previous DFT models might be over predicting the activation energies of the DODH reactions.

Previous work in our group investigated the effects of temperature, pressure, and catalyst loading on xylitol S-HDO utilizing parameter sweeps and a design of experiment [9]. It was found that $\mathrm{H}_{2}$ pressure had a zero-order relation with the conversion for xylitol S-HDO down to 10 bar. A linear Taguchi design did suggest that temperature had an inverse relationship between temperature and conversion, which was not expected due to the Arrhenius equation. To investigate this further, a general kinetics study of xylitol S-HDO is reported here with the goal to determine the reaction order, the reaction rate dependence on temperature, the activation energy, effects of xylitol concentration, and to evaluate mass transfer limitations. To the best of our knowledge, this is the first experimental study investigating the kinetics of xylitol simultaneous hydrodeoxygenation. This study was conducted to address the knowledge gap in the literature on the kinetics of simultaneous hydrodeoxygenation on non-cyclic sugar alcohols and substrates that have more than three hydroxyl groups. 
Table 1. Literature activation energies for similar deoxydehydration (DODH) reactions.

\begin{tabular}{|c|c|c|c|}
\hline Reaction/Catalyst & Activation Energy & Method & Reference \\
\hline $\begin{array}{l}\text { DODH of 1,4-anhydroerythritol over } \\
\qquad \mathrm{ReO}_{2} / \mathrm{CeO}_{2}\end{array}$ & $153 \mathrm{~kJ} / \mathrm{mol}$ & DFT & Ota et al., 2016 [11] \\
\hline $\begin{array}{c}\text { DODH of 1,4-anhydroerythritol over } \\
\text { ReO/ } / \mathrm{CeO}_{2}\end{array}$ & $109 \mathrm{~kJ} / \mathrm{mol}$ & DFT & Xi et al., 2018 [15] \\
\hline $\begin{array}{c}\text { DODH of 1,4-anhydroerythritol over } \\
\text { ReO-Pd } / \mathrm{CeO}_{2}\end{array}$ & $111 \mathrm{~kJ} / \mathrm{mol}$ & DFT & Xi et al., 2018 [15] \\
\hline $\begin{array}{l}\text { DODH of 1,4-anhydroerythritol over } \\
\qquad \operatorname{ReO}_{2}(2 \mathrm{O}) / \mathrm{TiO}_{2}(101)\end{array}$ & $71.4 \mathrm{~kJ} / \mathrm{mol}$ & DFT & Xi et al., 2020 [18] \\
\hline $\begin{array}{c}\text { DODH 1,4-anhydroerythritol over } \\
\mathrm{MoO}_{2}(2 \mathrm{O}) / \mathrm{TiO}_{2}(101)\end{array}$ & $160.2 \mathrm{~kJ} / \mathrm{mol}$ & DFT & Xi et al., 2020 [18] \\
\hline DODH of 3-Butene-1,2-diol over $\mathrm{CH}_{3} \mathrm{ReO}_{2}$ & $118.8 \mathrm{~kJ} / \mathrm{mol}$ & DFT & Wu et al., 2016 [16] \\
\hline $\begin{array}{l}\text { DODH of 3-Butene-1,2-diol over } \\
\qquad \mathrm{CH}_{3} \mathrm{ReO}(\mathrm{OH})_{2}\end{array}$ & $79.9 \mathrm{~kJ} / \mathrm{mol}$ & DFT & Wu et al., 2016 [16] \\
\hline $\begin{array}{l}\text { DODH of methyl } \alpha \text {-L-rhamnopyranoside over } \\
\qquad \mathrm{ReO}_{\mathrm{x}}-\mathrm{Pd} / \mathrm{CeO}_{2}\end{array}$ & $65,63 \mathrm{~kJ} / \mathrm{mol}$ & DFT, Arrhenius & Cao et al., 2020 [17] \\
\hline $\begin{array}{l}\text { DODH of methyl } \alpha \text {-L-fucopyranoside over } \\
\qquad \operatorname{ReO}_{x}-\mathrm{Pd} / \mathrm{CeO}_{2}\end{array}$ & $77,73 \mathrm{~kJ} / \mathrm{mol}$ & DFT, Arrhenius & Cao et al., 2020 [17] \\
\hline
\end{tabular}

\section{Results and Discussion}

\subsection{Catalyst Characterization}

The $\mathrm{ReO}_{\mathrm{x}}-\mathrm{Pd} / \mathrm{CeO}_{2}$ catalysts were characterized using X-ray Fluorescence Spectroscopy (XRF), X-ray Diffraction (XRD), Temperature Programmed Reduction (TPR), Scanning Electron Microscopy (SEM), Inductively Coupled Plasma-Optical Emission Spectrometry (ICP-OES), and Raman Spectroscopy.

\subsubsection{XRF}

XRF on the $\mathrm{ReO}-\mathrm{Pd} / \mathrm{CeO}_{2}$ catalyst showed that both the Re and Pd were uniformly distributed with standard deviations of $0.075 \mathrm{wt} \%$ and $0.054 \mathrm{wt} \%$, respectively. Pd had a higher coefficient of variation percentage (ratio between standard deviation and mean) of $7.17 \%$, suggesting a higher variation in the distribution. The Re and Pd XRD composition contours are shown in Figure S1. The various X-Y scans showed that the regions of higher Re concentration also had a higher concentration of Pd. Likewise, the regions of lower Re concentration also have a lower concentration of Pd, suggesting that the ratio of Re:Pd is relatively uniform throughout the sample.

\subsubsection{ICP-OES}

ICP-OES was conducted to determine the loading of $\mathrm{Re}$ and $\mathrm{Pd}$ in the $\mathrm{ReO}-\mathrm{Pd} / \mathrm{CeO}_{2}$ catalysts. The three batches of catalyst used in this study were analyzed for both $\mathrm{Re}$ and $\mathrm{Pd}$ and had a nominal loading of $2.0 \mathrm{wt} \% \mathrm{Re}$ and $0.30 \mathrm{wt} \% \mathrm{Pd}$. Three runs of each sample were analyzed in the ICP-OES and the errors presented are the standard deviation of the runs. The batches were determined to have an actual loading of $1.86 \pm 0.02 \mathrm{wt} \%, 1.89 \pm 0.01 \mathrm{wt} \%$, and $1.90 \pm 0.02 \mathrm{wt} \%$ of Re, respectively, and $0.217 \pm 0.003 \mathrm{wt} \%, 0.204 \pm 0.002 \mathrm{wt} \%$, and $0.202 \pm 0.001 \mathrm{wt} \%$ of $\mathrm{Pd}$, respectively.

\subsubsection{SEM}

SEM was conducted to determine the particle size of the $\mathrm{ReO}_{\mathrm{x}}-\mathrm{Pd} / \mathrm{CeO}_{2}$ catalyst. From the SEM images shown in Figure 2, we see that the morphology of the particles does not change during the synthesis of the $\mathrm{ReO}_{\mathrm{x}}-\mathrm{Pd} / \mathrm{CeO}_{2}$ catalyst. However, some changes in the distribution of the size of the particles between the support and the catalyst are observed. The distribution of particle sizes for the $\mathrm{CeO}_{2}$ and the $\mathrm{ReO}-\mathrm{Pd} / \mathrm{CeO}_{2}$ are shown in Figure 2c,d, respectively. The average particle size (diameter) for the $\mathrm{CeO}_{2}$ and $\mathrm{ReO}_{x^{-}}$ $\mathrm{Pd} / \mathrm{CeO}_{2}$ were 3.00 and $4.30 \mu \mathrm{m}$, respectively. The distribution of the particle sizes was a slightly skewed left distribution for $\mathrm{CeO}_{2}$ particles and a unimodal slightly skewed right 
distribution for the $\mathrm{ReO}_{\mathrm{x}}-\mathrm{Pd} / \mathrm{CeO}_{2}$ particles. The catalyst particles, on average, are more likely to be larger in size, which shows that the synthesis parameters and environment are causing a small agglomeration of the $\mathrm{CeO}_{2}$ particles. Low and high magnification SEM images of the $\mathrm{CeO}_{2}$ and $\mathrm{ReO}_{\mathrm{x}}-\mathrm{Pd} / \mathrm{CeO}_{2}$ are shown in Figure S2.
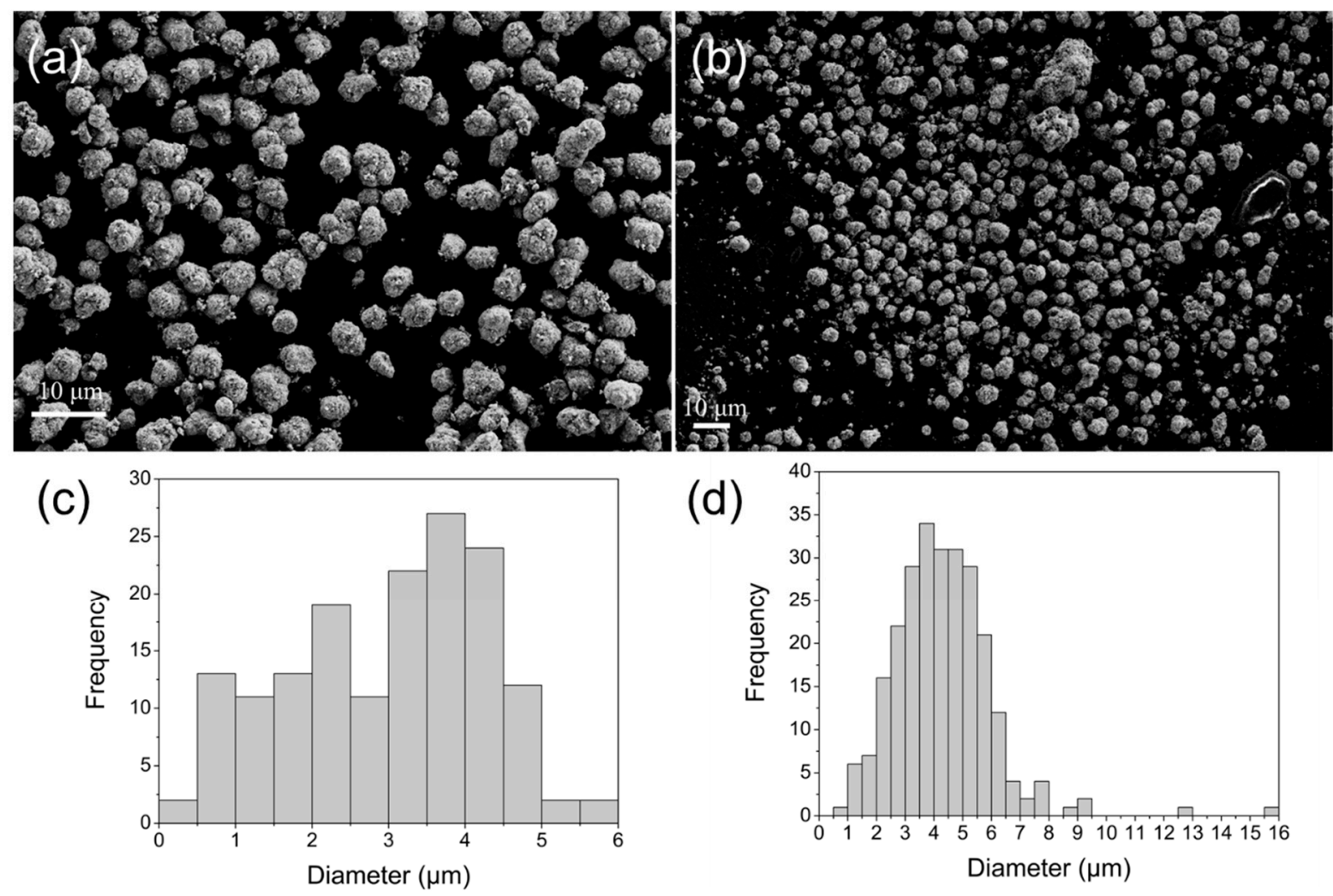

Figure 2. $\mathrm{SEM}$ of $\mathrm{CeO}_{2}$ support and $\mathrm{ReO}_{\mathrm{x}}-\mathrm{Pd} / \mathrm{CeO}_{2}$ catalyst. (a) $\mathrm{CeO}_{2} 1280 \times$ magnification $(\mathbf{b}) \mathrm{ReO}-\mathrm{Pd}_{\mathrm{x}} / \mathrm{CeO}_{2}$ $629 \times$ magnification $\left(\right.$ c) $\mathrm{CeO}_{2}$ particle size histogram (d) $\mathrm{ReO}_{\mathrm{x}}-\mathrm{Pd} / \mathrm{CeO}_{2}$ particle size histogram.

\subsubsection{TPR}

TPR was conducted to determine the temperature at which reduction events would occur. The batches of catalyst showed similar results in the TPR, as shown in Figure S4. There were two distinct reduction events at $147^{\circ} \mathrm{C}$ and $183^{\circ} \mathrm{C}$. Similar reduction events have been previously reported in TPR profiles for a $2 \mathrm{wt} \% \mathrm{ReO}_{\mathrm{x}}-\mathrm{Pd} / \mathrm{CeO}_{2}(0.30 \mathrm{wt} \% \mathrm{Pd})$ catalyst [9].

\subsubsection{In-Situ Raman}

In-situ Raman was conducted to investigate what structures of $\mathrm{ReO}_{\mathrm{x}}$ were present under reaction conditions. The $100{ }^{\circ} \mathrm{C}, 140{ }^{\circ} \mathrm{C}$, and $180^{\circ} \mathrm{C}$ fitted spectra are shown in Figure 3. The mono-oxo, di-oxo, oligomeric crosslinked, and hydroxyl structures were present in the sample, as assigned by MacQueen et al. [19]. The mono-oxo vibrational band is located at $994 \mathrm{~cm}^{-1}$. The di-oxo bands are located at 988 and $972 \mathrm{~cm}^{-1}$ for the symmetric and asymmetric stretches, respectively. The oligomeric crosslinked band was located at $888 \mathrm{~cm}^{-1}$, and the hydroxyl band was located at $832 \mathrm{~cm}^{-1}$. The full-width half maximums were fixed for each respective band across spectra, and the areas of the symmetric and asymmetric stretch bands were constrained to be equivalent during fitting. As the temperature is increased, the area of the di-oxo species bands increases, and the mono-oxo bands decrease. The increase in the concentration of the di-oxo species can be attributed to an increase in oxygen migration from the ceria support as the temperature is increasing, which has previously been reported in other ceria systems in the literature [20]. 
Ceria is able to store and release oxygen due to the stability of $\mathrm{Ce}^{3+}$ and $\mathrm{Ce}^{4+}$, which allows for the ceria to shift between $\mathrm{CeO}_{2}$ and $\mathrm{CeO}_{2-x}$ [21-24]. The area of the hydroxyl band also slightly decreases as the temperature is increased. However, no new bands are formed while the temperature is increased.

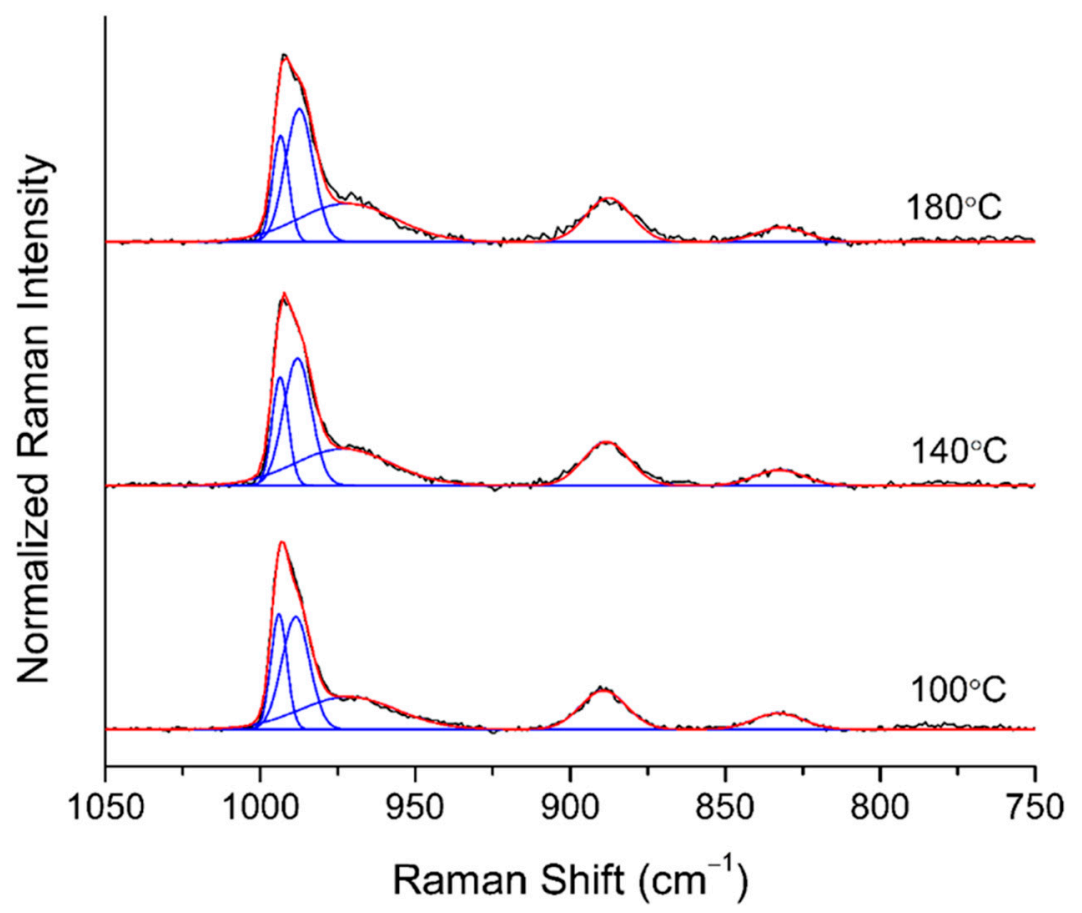

Figure 3. In-situ Raman spectra of a $2 \mathrm{wt} \% \mathrm{ReO}_{\mathrm{x}}-\mathrm{Pd} / \mathrm{CeO}_{2}$ catalyst at $100{ }^{\circ} \mathrm{C}, 140{ }^{\circ} \mathrm{C}$, and $180{ }^{\circ} \mathrm{C}$ under an Ar environment.

\subsection{Reaction Order Determination}

The reaction order with respect to xylitol concentration of the xylitol S-HDO over the $\mathrm{ReO}-\mathrm{Pd} / \mathrm{CeO}_{2}$ catalyst was determined by conducting reactions at various temperatures ranging from $120^{\circ} \mathrm{C}$ and $170{ }^{\circ} \mathrm{C}$ and fitting the product concentrations to respective reaction order fittings. Zero, first, and second-order fittings were applied to the data for evaluation. It was determined that the xylitol S-HDO was a zero-order reaction. This reaction using other substrates has been reported as zero-order in the literature [17]. The reaction concentration profiles of the reactant and products and the zero-order fit for the $160^{\circ} \mathrm{C}$ reaction are shown in Figure 4 . The volume of the reaction remains virtually constant throughout the reaction with only a negligible $(\sim 300 \mu \mathrm{L})$ amount of volume being removed for sampling for analysis. The selectivity to 1,2-dideoxypentitol was slightly higher than to 1,2,5-pentanetriol, which was previously reported in the literature [9]. The reaction order fitting for the zero-order case showed significantly better fit and higher $\mathrm{R}^{2}$ values of 0.997 for xylitol and 0.998 and 0.993 for 1,2-dideoxypentitol and 1,2,5-pentanetriol, respectively. This trend was exhibited at all reaction temperatures, but the first-order fitting was comparable to the zero-order fit at some reaction temperatures. However, when comparing the product fits, the reaction in all cases is clearly zero-order. Since in all cases, the zero-order fitting was consistently the best fit, the reaction of xylitol S-HDO over the $\mathrm{ReO}_{\mathrm{x}}-\mathrm{Pd} / \mathrm{CeO}_{2}$ was determined to be a zero-order reaction, and thus there was no effect of xylitol concentration during the reaction. 


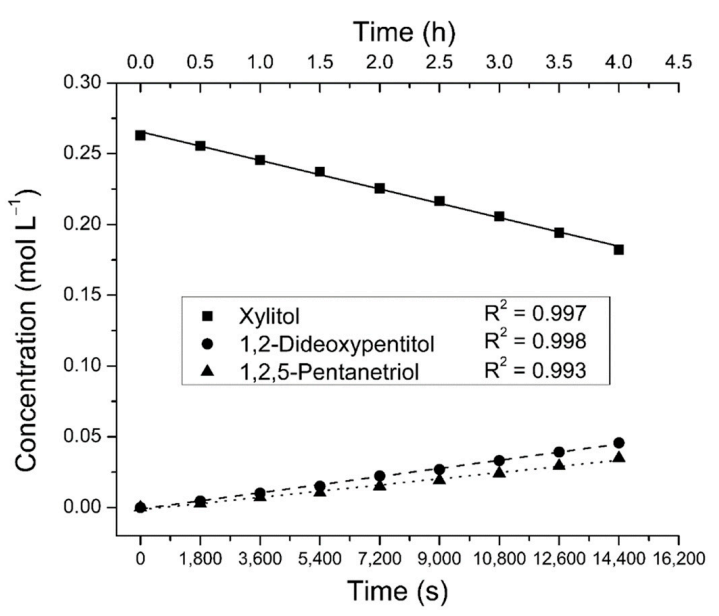

Figure 4. Reaction order fittings for the simultaneous hydrodeoxygenation (S-HDO) of xylitol over $\mathrm{ReO}_{\mathrm{x}}-\mathrm{Pd} / \mathrm{CeO}_{2}$ at $160{ }^{\circ} \mathrm{C}$.

In previous studies, it was reported that over a wide range of $\mathrm{H}_{2}$ reaction pressures down to 10 bar, the reaction pressure exhibited a zero-order relation for the S-HDO of 1,4-anhydroerythritol and xylitol [9]. The pressure reaction order has been determined to be near zero for other reactants for the S-HDO reaction over $\mathrm{ReO}_{x}-\mathrm{Pd} / \mathrm{CeO}_{2}$ [17]. Thus, the general reaction equation is determined to be the following:

$$
\begin{aligned}
& \mathrm{C}_{5} \mathrm{H}_{12} \mathrm{O}_{5}+2 \mathrm{H}_{2} \rightarrow \mathrm{C}_{5} \mathrm{H}_{12} \\
& \text { Rate }=k\left[\mathrm{C}_{5} \mathrm{H}_{12} \mathrm{O}_{5}\right]^{0}\left[\mathrm{H}_{2}\right]^{0}=k
\end{aligned}
$$

\subsection{Activation Energy Determination}

To determine the activation energy of the xylitol S-HDO, reactions between 150 and $170{ }^{\circ} \mathrm{C}$ were tested. The resulting reaction rates were then plotted in an Arrhenius plot, as shown in Figure 5. Below $150^{\circ} \mathrm{C}$, the reaction rates were significantly lower and had a lower Arrhenius slope, which resulted in a lower activation energy. The increasing concentration of the di-oxo species at higher temperatures seen in the Raman could explain the higher reaction rates seen above $140^{\circ} \mathrm{C}$. If the di-oxo species is the active species for S-HDO as previously proposed in Ota et al. [11], then along with the temperature effects on reaction rate, having a higher concentration of the di-oxo species could also significantly increase the reaction rate. However, $\mathrm{Xi}$ et al. [19] proposed that the mono-oxo species could be the active site, but since the activity increases as the concentration of the di-oxo species increases, it is likely that the active site is the di-oxo species. The lower reaction rates observed below $150^{\circ} \mathrm{C}$ can also be attributed to the $\mathrm{ReO}_{\mathrm{x}}$ species not reducing since the first significant reduction event occurred at $147^{\circ} \mathrm{C}$ in TPR. Thus, only temperatures above $150{ }^{\circ} \mathrm{C}$ were considered. The Arrhenius plot linear fit had an $\mathrm{R}^{2}$ value of 0.9864 , with respective data points having a standard error of 0.0116. The slope of the Arrhenius plot is equal to the $-E_{a} / R$, in which $E_{a}$ is the apparent activation energy and $R$ is the universal gas constant. From the Arrhenius plot, the apparent activation energy was determined to be $48.7 \pm 10.5 \mathrm{~kJ} / \mathrm{mol}$, and the pre-exponential constant was determined to be $0.38 \mathrm{~mol}$ $\mathrm{s}^{-1} \mathrm{~g}_{\mathrm{cat}}{ }^{-1}$. The activation energy error was determined using $95 \%$ confidence intervals for the slope coefficient from the linear regression. The resulting Arrhenius equation for this reaction is as follows:

$$
\begin{gathered}
k=A e^{-\mathrm{E}_{\mathrm{a}} / R T} \\
k=0.38 \frac{\mathrm{mol}}{\mathrm{s} \times \mathrm{g}_{\text {cat }}} e^{-\left(48.7 \frac{\mathrm{kJ}}{\mathrm{mol}}\right) /\left(8.314 \frac{\mathrm{J}}{\mathrm{mol} \times \mathrm{K}} \times T\right)}
\end{gathered}
$$




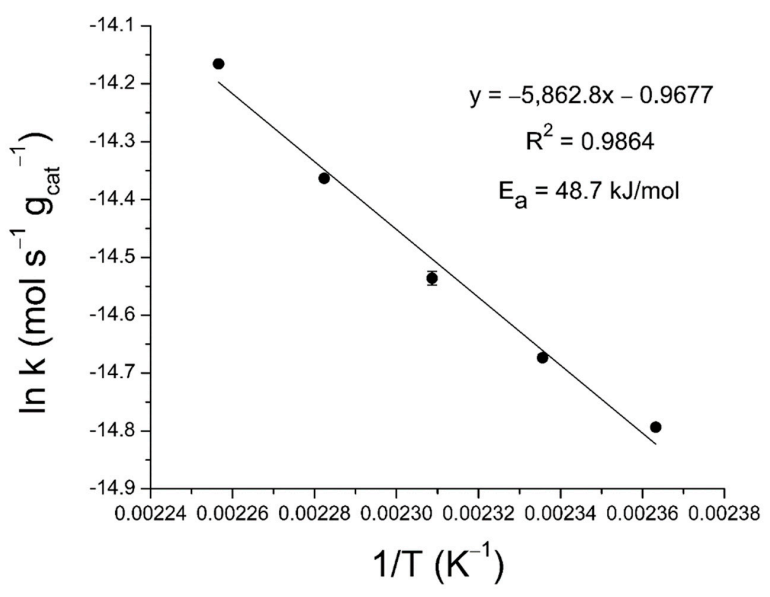

Figure 5. Arrhenius plot for the S-HDO of xylitol.

Since the reaction rates seemed to exhibit a non-linear trend at lower temperatures, nonArrhenius kinetic parameter determination was conducted utilizing reaction temperatures of $120-170{ }^{\circ} \mathrm{C}$. It has been reported in the literature that for sub-Arrhenius and super-Arrhenius relations, the activation energy is dependent on temperature and can be accounted for by an additional quadratic term in the rate equation [25-28], as shown in Equation (5). The quadratic parameter $C$ determines the curvature and thus if the curve is concave (positive $C$ value) in the case of a sub-Arrhenius relation or convex (negative $C$ value) in the case of a super-Arrhenius relation. This additional term results in $\mathrm{E}_{\mathrm{a}}$ being dependent linearly on $1 / \mathrm{T}[26,27]$. Activation energy is thus equal to the partial derivative of the natural $\log$ of $k$ with respect to $1 / R T$, in which $\left(\frac{\partial \ln k}{\partial \frac{1}{R T}}\right)$ of Equation (5) results in Equation (6).

$$
\begin{gathered}
\ln k=\ln A+\frac{B}{R T}+\frac{C}{(R T)^{2}} \\
\mathrm{E}_{\mathrm{a}}=-B-\frac{2 C}{R T}
\end{gathered}
$$

The resulting non-Arrhenius behavior plot resulting from reaction temperatures of $120-170{ }^{\circ} \mathrm{C}$ is shown in Figure 6, and the associated kinetic parameters are shown in Table 2. The $C$ value was positive in this case leading to a concave curve characteristic for sub-Arrhenius behavior. The quadratic fitting of the sub-Arrhenius behavior improved the $\mathrm{R}^{2}$ value to 0.99 . The $95 \%$ confidence intervals were calculated for the respective kinetic parameters and are reported in Table 2.

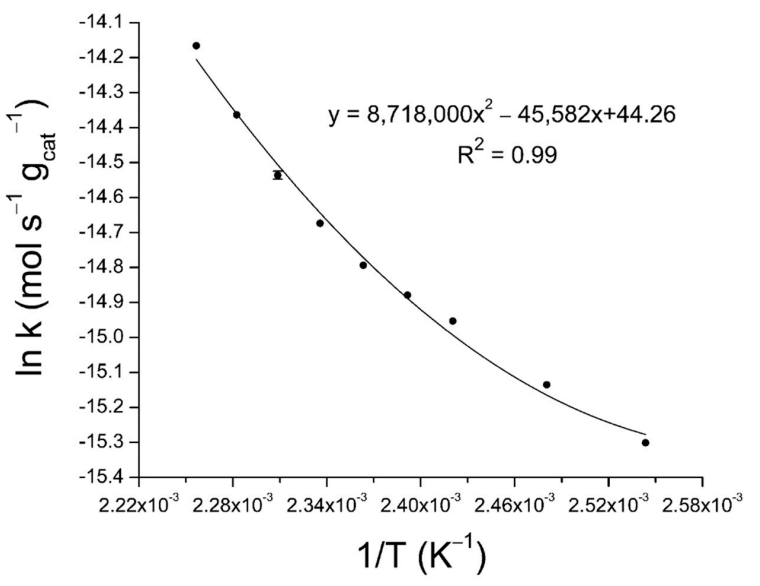

Figure 6. Sub-Arrhenius behavior plot for the S-HDO of xylitol. 
Table 2. Kinetic parameters for sub-Arrhenius behavior.

\begin{tabular}{ccc}
\hline Kinetic Parameter & Value & $\mathbf{9 5 \% ~ C I}$ \\
\hline A & $44 \mathrm{~mol} \mathrm{~s}^{-1} \mathrm{~g}_{\mathrm{cat}}{ }^{-1}$ & $(23,65)$ \\
$\mathrm{B}$ & $-3.79 \times 10^{5} \mathrm{~J} \mathrm{~mol}^{-1}$ & $\left(-5.76 \times 10^{5},-2.34 \times 10^{-5}\right)$ \\
$\mathrm{C}$ & $6.03 \times 10^{8} \mathrm{~J}^{2} \mathrm{~mol}^{-2}$ & $\left(3.52 \times 10^{8}, 8.53 \times 10^{8}\right)$ \\
\hline
\end{tabular}

The resulting activation energies over the range tested are reported in Table 3. In the temperature ranges tested, activation energy ranged from 10.2-51.8 $\mathrm{kJ} / \mathrm{mol}$. At the lower range of temperatures tested, the sub-Arrhenius activation energies greatly differ from the Arrhenius activation energy. However, at and above $155^{\circ} \mathrm{C}$, the Activation energies are within error of the Arrhenius calculated activation energy. The improved fit over the expanded temperature range strongly supports that sub-Arrhenius behavior is present, and thus, $\mathrm{E}_{\mathrm{a}}$ is a function of temperature for xylitol S-HDO in the temperature range tested in this study.

Table 3. Temperature-dependent activation energies from sub-Arrhenius behavior.

\begin{tabular}{cc}
\hline Temperature (K) & Activation Energy (kJ/mol) \\
\hline 393.15 & 10.2 \\
403.15 & 19.4 \\
413.15 & 28.1 \\
418.15 & 32.3 \\
423.15 & 36.4 \\
428.15 & 40.4 \\
433.15 & 44.3 \\
438.15 & 48.1 \\
443.15 & 51.8 \\
\hline
\end{tabular}

From the sub-Arrhenius behavior, we can calculate the barrier height $\left(E_{0}\right)$, the deformation parameter (d), and the penetration frequency $v^{*}$ [25]. The apparent activation energy is related to the barrier height and deformation parameter as follows:

$$
\frac{1}{\mathrm{E}_{\mathrm{a}}}=\frac{1}{E_{0}}-d \frac{1}{R T}
$$

where the deformation parameter $(d)$ is dependent on Planck's constant $(h)$, the penetration frequency $v^{*}$, and the barrier height $\left(E_{0}\right)$, as described by Bell's tunneling theory shown in Equation (8).

$$
d=-\frac{1}{3}\left(\frac{\mathrm{h} v^{*}}{2 E_{0}}\right)^{2}
$$

Using the activation energies and the respective reaction temperatures from Table 3 , $\mathrm{E}_{0}$ was determined to be $-2608 \mathrm{~J} / \mathrm{mol}$, and $v^{*}$ was determined to be $1.648 \times 10^{37} \mathrm{~mol}^{-1} \mathrm{~s}^{-1}$. These values are on the same order of magnitude as similar quantum tunneling for nonArrhenius behavior reported in the literature $[29,30]$. The deformation parameter can then be calculated using the values for $E_{0}$ and $v^{*}$ as shown in Equation (9).

$$
\frac{1}{\mathrm{E}}=\frac{1}{-2608 \frac{\mathrm{J}}{\mathrm{mol}}}-\frac{-\frac{1}{3}\left(\frac{6.626 \times 10^{-34} \mathrm{~J} \times \mathrm{s} \times 1.648 \times 10^{37} \frac{1}{\mathrm{~mol} \times \mathrm{s}}}{2 \times-2608 \frac{\mathrm{I}}{\mathrm{mol}}}\right)^{2}}{8.314 \frac{\mathrm{J}}{\mathrm{K} \times \mathrm{mol}} \times \mathrm{T}}
$$

The deformation parameter was determined to be $d=-1.461$. The value of $\mathrm{d}$ is negative which is further indicative of sub-Arrhenius behavior. $E_{0}$ and $d$ can be plugged into Equation (7) which results in the following:

$$
\overline{\mathrm{E}}_{\mathrm{a}}=\frac{1}{-2608 \frac{J}{\mathrm{~mol}}}-\frac{-1.461}{8.314 \frac{\mathrm{J}}{\mathrm{K} \times \mathrm{mol}} \times T}
$$


Euler's celebrated limit can then be used to describe the sub-Arrhenius behavior in terms of the deformed Arrhenius equation [25] as shown in Equation (11). Using the kinetic parameter, A from the sub-Arrhenius fitting, the deformation parameter, and the barrier height, the resulting rate equation based on Euler's celebrated limit is shown in Equation (12).

$$
\begin{gathered}
k(T)=A\left[1-d \frac{E_{0}}{R T}\right]^{\frac{1}{d}} \\
k=44 \frac{\mathrm{mol}}{\mathrm{s} \times \mathrm{g}_{\text {cat }}}\left[1-\left(-1.461 \frac{-2608 \frac{\mathrm{m}}{\mathrm{mol}}}{8.314 \frac{\mathrm{J}}{\mathrm{mol} \times \mathrm{K}} \times T}\right)\right]^{\frac{1}{-1.461}}
\end{gathered}
$$

The activation energies reported here for xylitol S-HDO in the case of Arrhenius and sub-Arrhenius kinetics are lower than reported literature values for other compounds previously discussed [16-19]. Recently, Cao et al. reported theoretical and experimental activation energies that were also significantly lower than previously reported activation energies for similar reactions [17]. Cao et al. evaluated the S-HDO reaction for several methyl glycosides over $\mathrm{ReO}-\mathrm{Pd} / \mathrm{CeO}_{2}$ and used DFT to model the reaction mechanisms. They found the reaction order with respect to the substrate concentration and hydrogen to be almost zero. This result suggests that the active site is almost saturated with methyl glycosides during the reaction. It also suggests that the rate-determining step is not the coordination of the substrate to the Re species or the hydrogenation reaction, but rather that the desorption step is the rate-determining step. Similarly, the desorption step is likely the rate limiting step for xylitol S-HDO. However, there could also be a limitation due to a reaction between the adsorbed pentene-triols with hydrogen on the catalyst surface. This occurs when the equilibrium is completely shifted to the right for hydrogenation as reported in other systems in the literature [31,32]. Further modeling and DFT calculations would be needed to investigate this potential limitation. Cao et al. evaluated methyl $\alpha$-L-rhamnopyranoside and methyl $\alpha$-L-fucopyranoside, which are stereoisomers, as model compounds for methyl glycosides. They found a near 5-fold difference in the reactivity of the methyl glycosides with the methyl $\alpha$-L-rhamnopyranoside having the higher reaction rate, suggesting that geometric orientation of the $\mathrm{OH}$ functional groups plays a significant role in the activity. This was also seen in the Arrhenius plots which showed that the methyl $\alpha$-L-rhamnopyranoside $(63 \mathrm{~kJ} / \mathrm{mol})$ had an activation energy that was $10 \mathrm{~kJ} / \mathrm{mol}$ lower than methyl $\alpha$-L-fucopyranoside $(73 \mathrm{~kJ} / \mathrm{mol})$. Cao et al. also attributed the activation energy difference between the methyl glycosides to the substrates having either different transition states or adsorption states due to their differing geometry.

The activation energy for xylitol S-HDO we report is lower than reported by Cao et al. for the methyl glycosides but is much closer to their reported experimental values than previous theoretical calculations in the literature. There are several possibilities why the activation energy for xylitol S-HDO is lower than the other reported reactions. The more simplistic structure of xylitol as compared to other reported compounds modeled could explain the disparity. Xylitol has five cis-vicinal hydroxyl groups, which could make it more likely for the xylitol to adsorb to the $\mathrm{ReO}_{\mathrm{x}}$ since there are multiple pairs of hydroxyl groups that have the possibility of adsorbing to the catalyst. As seen by the two products, 1,2-dideoxypentitiol and 1,2,5-pentanetriol, the $C_{1}-C_{2}$ or $C_{2}-C_{3}$ hydroxyl groups can be adsorbed and undergo the S-HDO. It has been shown for other sugars in similar reactions that the reaction rate was dependent on the stereochemical configuration and strongly influenced the adsorption and activation energy [33]. It has also been shown that for the S-HDO of methyl glycosides that only the cis-vicinal $\mathrm{OH}$ groups can be selectively removed and that the trans-vicinal $\mathrm{OH}$ groups can still be adsorbed on the active site but suppresses the reaction [14]. However, the additional hydroxyl groups could potentially cause steric hindrance. It has also been shown for the hydrogenolysis of glycerol that due to steric reasons, the primary hydroxyl group is cleaved more readily as compared to secondary hydroxyl groups [34]. This could explain the higher selectivity to 1,2-dideoxypentitiol, which 
is formed from the cleavage of a primary and a secondary hydroxyl group as compared to 1,2,5-pentanetriol, which forms due to the cleavage of two secondary hydroxyl groups. Xylitol has two primary hydroxyl groups, which can also potentially be a reason why the activation energy is lower as compared to the other substrates, such as 1,4-anhydroerythritol and methyl $\alpha$-L-rhamnopyranoside, which contain only secondary hydroxyl groups. For the DODH of methyl $\alpha$-L-rhamnopyranoside and methyl $\alpha$-L-fucopyranoside, as shown in Cao et al., reactants had three vicinal hydroxyl groups, and the resulting reaction had a lower activation energy than for compounds such as 1,4-anhydroerythritol [15,19], which have two vicinal hydroxyl groups. There may be a relation between the number of available vicinal hydroxyl groups and the activation energy of the reaction. In the literature, it has been reported that the reaction rate of dehydration in sugar alcohols is correlated to the strength of the $\mathrm{C}-\mathrm{O}$ bond $[35,36]$. The $\mathrm{C}-\mathrm{O}$ bond strength has an inverse relationship with the number of hydroxyl groups on the alcohol. The more $\mathrm{OH}$ groups the alcohol contains, the lower the $\mathrm{C}-\mathrm{O}$ bond strength, which results in a higher reaction rate. It is also possible that there could be a significant difference between the activation energies for cyclic molecules and xylitol, which is a straight chain. However, more work needs to be performed to fully investigate why the activation energy is lower in comparison.

\subsection{Mass Transfer Evaluations}

\subsubsection{Weisz-Prater Criterion}

The Weisz-Prater criterion was evaluated to determine if internal diffusion limitations were present. The criterion was calculated from the following equation:

$$
C_{W P}=\frac{-r_{A}(o b s) \times \rho_{c} \times R^{2}}{D_{e} \times C_{A S}}
$$

The reaction rate observed is $r_{A}, \rho_{c}$ is the density of ceria, $R$ is the radius of the $\mathrm{ReO}_{\mathrm{x}}-\mathrm{Pd} / \mathrm{CeO}_{2}$ particles, which was determined from $\mathrm{SEM}, \mathrm{D}_{e}$ is the effective diffusivity, and $C_{A S}$ is the reactant concentration at the particle surface. For the liquid-liquid diffusion, $D_{e}$ is estimated/assumed to be on the order of $10^{-9} \mathrm{~m}^{2} / \mathrm{s}$ based on similar reactions reported in the literature [37-40]. However, to be conservative, we are estimating $D_{e}$ to be on the order of $10^{-10}$. The lowest concentration of xylitol during a reaction point in this study was used for $C_{A S}$ to be conservative. With the resulting terms for xylitol, the result is as follows:

$$
\begin{gathered}
C_{W P}=\frac{7.04 \times 10^{-4}\left(\frac{m o l}{k g \times s}\right) \times 7220\left(\frac{\mathrm{kg}}{\mathrm{m}^{3}}\right) \times\left(2.15 \times 10^{-6}\right)^{2}\left(\mathrm{~m}^{2}\right)}{10^{-10}\left(\frac{\mathrm{m}^{2}}{\mathrm{~s}}\right) \times 51\left(\frac{\mathrm{mol}}{\mathrm{m}^{3}}\right)} \\
C_{W P}=4.61 \times 10^{-3}, C_{W P} \ll 1
\end{gathered}
$$

Since the Weisz-Prater criterion is much less than 1 for xylitol, it can be assumed that no internal diffusion limitations are present for xylitol diffusion in the reaction.

For hydrogen diffusing in the solvent, the $\mathrm{D}_{\mathrm{e}}$ and $\mathrm{C}_{\mathrm{AS}}$ values change. For hydrogen, $\mathrm{D}_{\mathrm{e}}$ has been reported to be on the order of $10^{-9} \mathrm{~m}^{2} / \mathrm{s}$ in 1,4-dioxane [37]. However, to be conservative, we are using a $D_{e}$ value of $10^{-10}$. $C_{\text {AS }}$ was estimated by using Henry's law and solubility data for $\mathrm{H}_{2}$ in 1,4-dioxane from the literature [41]. Based on the enthalpy, entropy, and mole fraction solubility data presented, a Henry's law constant $\left(\mathrm{k}_{\mathrm{H}}\right)$ of $3.89 \times 10^{-4} \mathrm{~mol} \mathrm{~kg}^{-1} \mathrm{bar}^{-1}$ was calculated. $C_{A S}$ was calculated based on $10 \mathrm{bar} \mathrm{H}_{2}$ pressure, and $\mathrm{H}_{2}$ is the only gas in the reactor. The result was $4.01 \mathrm{~mol} / \mathrm{m}^{3}$. With the resulting terms for hydrogen, the result is as follows:

$$
\begin{gathered}
C_{W P}=\frac{7.04 \times 10^{-4}\left(\frac{\mathrm{mol}}{\mathrm{kg} \times s}\right) \times 7220\left(\frac{\mathrm{kg}}{\mathrm{m}^{3}}\right) \times\left(2.15 \times 10^{-6}\right)^{2}\left(\mathrm{~m}^{2}\right)}{10^{-10}\left(\frac{\mathrm{m}^{2}}{\mathrm{~s}}\right) \times 4.01\left(\frac{\mathrm{mol}}{\mathrm{m}^{3}}\right)} \\
C_{W P}=5.86 \times 10^{-2}, C_{W P} \ll 1
\end{gathered}
$$


Since the Weisz-Prater criterion is much less than 1 for hydrogen, it can be safely assumed that no internal diffusion limitations are present for hydrogen diffusion in the reaction.

\subsubsection{External Mass Transfer}

External mass transfer limitations were investigated by varying the stirring rate of the magnetic stir bar within the reactor over a wide range. Stir rates of 150-700 rpm were evaluated for the xylitol S-HDO at $160{ }^{\circ} \mathrm{C}$ at the reaction concentrations previously discussed. The reaction rates as a function of the stirring rate are shown in Figure 7 . There was no significant difference between any of the reactions conducted over this stirring rate range, as all of the reaction rates were within experimental error of each other. The standard error for the $550 \mathrm{rpm}$ reaction was calculated from three separate reactions at the same condition and was determined to be $9.81 \times 10^{-9} \mathrm{~mol} \mathrm{~s}^{-1} \mathrm{~g}_{\mathrm{cat}}{ }^{-1}(2.02 \%)$. Since there was no significant difference by varying the stirring rate, there is no evidence of external mass transfer limitations being present during the reactions.

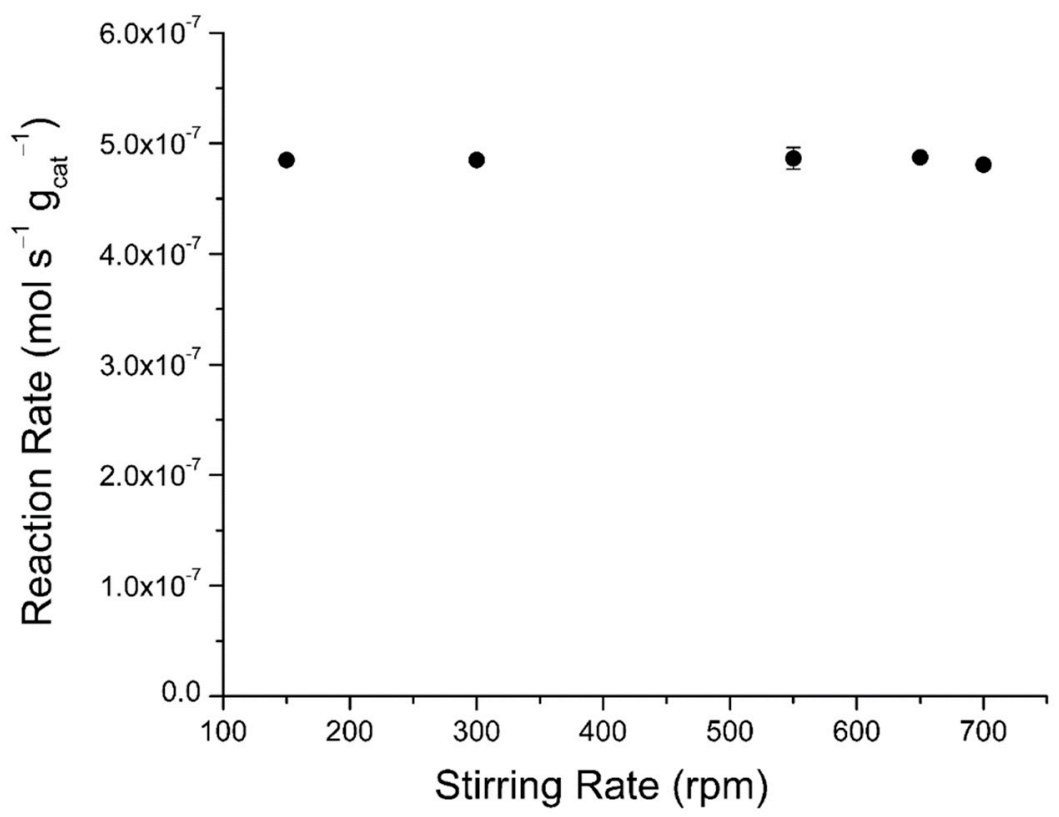

Figure 7. Evaluation of mixing and associated mass transfer.

\subsubsection{Xylitol Concentration Effects}

The effect of xylitol concentration on the reaction rate was also investigated. Reactions were conducted by varying the xylitol concentration from $0.962-13.4 \mathrm{wt} \%$ (0.5-8 g) while keeping the reactant to catalyst weight ratio constant $(0.30 \mathrm{~g}$ catalyst: $1 \mathrm{~g}$ xylitol$)$. For each reaction, $50 \mathrm{~mL}$ of solvent (1,4-dioxane) was used, and the reaction temperature utilized was $160{ }^{\circ} \mathrm{C}$. The reaction rate as a function of xylitol concentration is shown in Figure 8 . The reaction rate on a mol s${ }^{-1}$ basis increases linearly in the $0.962-7.21 \mathrm{wt} \%$ region, as seen in Figure 8a. Above the $7.21 \mathrm{wt} \%$ ( $4 \mathrm{~g}$ ) point, the reaction rate still increases, but the increase in reaction rate is lower than expected based on a linear trend. It is likely that above $7.21 \mathrm{wt} \%$ of xylitol, significant solubility issues occur, and that the undissolved xylitol could be blocking the catalyst in the reaction mixture and preventing it from adsorbing dissolved xylitol. When the reaction rates were normalized to the mass of catalyst, the rates in the $0.962-7.21 \mathrm{wt} \%$ region were comparable, but the $3.74 \mathrm{wt} \%(2 \mathrm{~g})$ rate was slightly higher, as shown in Figure $8 \mathrm{~b}$. The standard error of the $3.74 \mathrm{wt} \%$ reaction rate was $9.81 \times 10^{-9} \mathrm{~mol} \mathrm{~s}^{-1} \mathrm{~g}_{\mathrm{cat}}{ }^{-1}(2.02 \%)$, based on three experimental runs. 

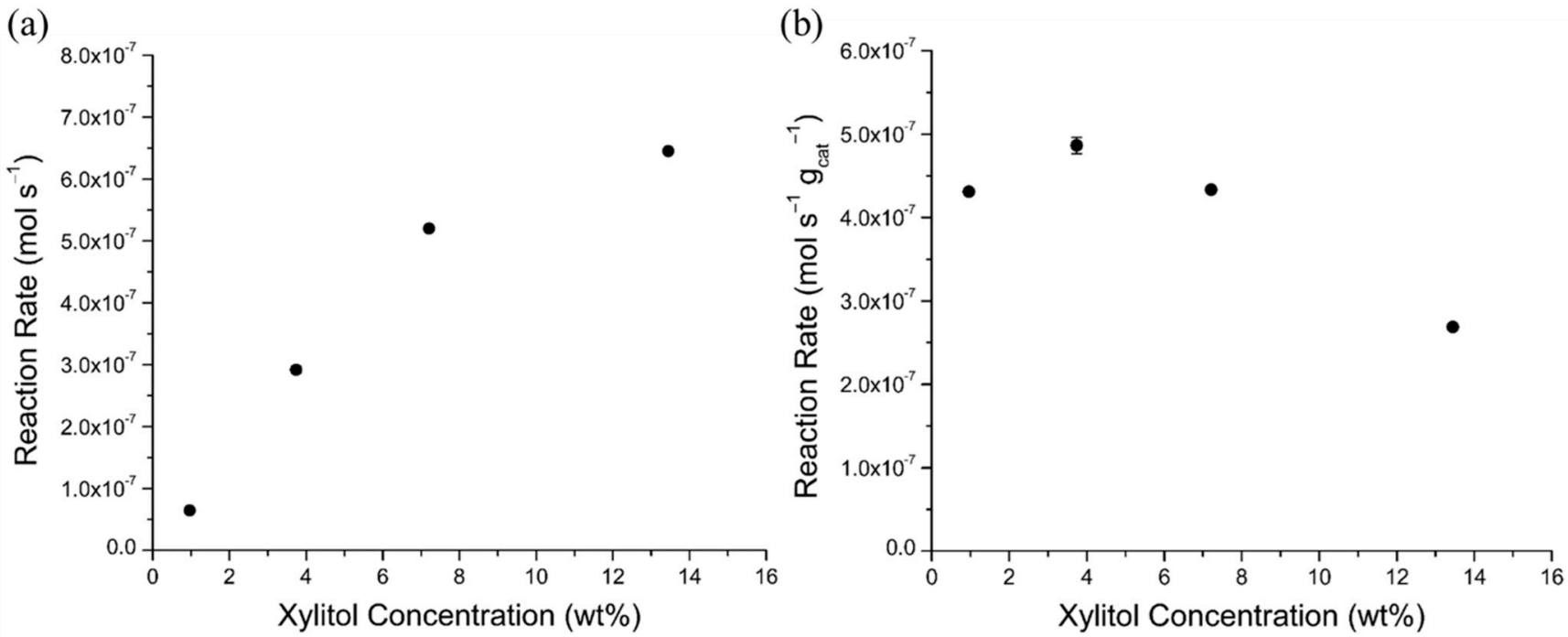

Figure 8. Xylitol concentration effect on reaction rate at $160{ }^{\circ} \mathrm{C}$. (a) Rate in $\mathrm{mol} \mathrm{s}{ }^{-1}$, (b) rate in mol s $\mathrm{gcat}^{-1}$.

\section{Experimental}

\subsection{Chemicals}

Xylitol (CAS No. 87-99-0) $\geq 99 \%$, 1,4-Dioxane (CAS No. 123-91-1) 99.9\%, 1,2,5Pentanetriol (CAS No. 14697-46-2) 97\%, 1,2-Pentanediol (CAS No. 5343-92-0) 96\%, 1-Pentanol (CAS No. 71-41-0) $\geq 99 \%$, 3-Pentanol (CAS No. 584-02-1) 98\%, Ammonium perrhenate (CAS No. 13598-65-7) $\geq 99 \%$, Palladium (II) nitrate (10 wt $\%$ in $10 \mathrm{wt} \%$ nitric acid) (MDL: MFCD00011169) 99.999\%, Cerium (IV) oxide (CAS No. 1306-38-3), and Ultra High Purity (UHP) Hydrogen (CAS No. 1333-74-0) 99.999\%, were used in this study. The cerium (IV) oxide was donated by Daiichi Kigenso Kagaku Kogyo Co., Ltd. Osaka, Japan. The UHP hydrogen was obtained from Praxair, the 1,2,5-Pentanetriol was obtained from Combi-Blocks, the 1,4-Dioxane was obtained from Fisher Chemical, and all remaining above-mentioned chemicals were obtained from Sigma-Aldrich.

\subsection{Catalyst Preparation}

The $\mathrm{ReO}_{\mathrm{x}}-\mathrm{Pd} / \mathrm{CeO}_{2}$ catalysts were prepared via wet impregnation following the procedures previously reported by Ota et al. and MacQueen et al. $[9,19]$. The $\mathrm{CeO}_{2}$ support was first calcined in air at $600{ }^{\circ} \mathrm{C}$ for $3 \mathrm{~h}$ with a ramping rate of $10^{\circ} \mathrm{C} / \mathrm{min}$. Following the support calcination, the $\mathrm{ReO}_{x}$ was then impregnated onto the $\mathrm{CeO}_{2}$ via wet impregnation using the desired amount of ammonium perrhenate $\left(\mathrm{NH}_{4} \mathrm{ReO}_{4}\right)$ dissolved in an aqueous solution while being mixed on a stir plate at $300 \mathrm{rpm}$. Once the solution was adequately mixed, it was dried at $110^{\circ} \mathrm{C}$ for $12 \mathrm{~h}$ to allow the water to evaporate from the solution and leave only the $\mathrm{ReO}_{x} / \mathrm{CeO}_{2}$. Then the palladium was impregnated via wet impregnation using an aqueous solution of the desired amount of palladium (II) nitrate $\left(\mathrm{Pd}\left(\mathrm{NO}_{3}\right)_{2}\right)$ in the same manner as the $\mathrm{ReO}_{\mathrm{x}}$ was impregnated. The solution was then dried at $110{ }^{\circ} \mathrm{C}$ for $12 \mathrm{~h}$ and then subjected to calcination in air at $500{ }^{\circ} \mathrm{C}$ for $3 \mathrm{~h}$ with a ramping rate of $10{ }^{\circ} \mathrm{C} / \mathrm{min}$. Post calcination, the resulting $\mathrm{ReO}_{\mathrm{x}}-\mathrm{Pd} / \mathrm{CeO}_{2}$ catalyst was ground into a fine powder with a mortar and pestle. All of the $\mathrm{ReO}-\mathrm{Pd} / \mathrm{CeO}_{2}$ catalysts used in this study were made with a nominal loading of $2 \mathrm{wt} \% \mathrm{Re}$ and $0.30 \mathrm{wt} \% \mathrm{Pd}$, respectively to ensure that the molar ratio of $\mathrm{Pd}$ to $\mathrm{Re}$ was $\mathrm{Pd} / \mathrm{Re}=0.25$.

\subsection{Catalyst Characterization}

\subsubsection{XRF}

XRF was conducted on a Fischerscope XDAL system utilizing a $0.30 \mathrm{~mm}$ collimator size and an $80 \mathrm{~s}$ measurement time. XRF was conducted to ensure that the Re and $\mathrm{Pd}$ were uniformly distributed within the catalyst. The XRF was used in standard free mode, 
and thus the percentages reported are not exact values but can still give insight into the distribution of the elements. The catalyst powder was placed in an XRD sample holder (diameter of $24 \mathrm{~mm}$ and a depth of $2 \mathrm{~mm}$ ), and then 11 random points away from the edges were scanned for $\mathrm{Re}, \mathrm{Pd}$, and Ce to determine the respective concentrations.

\subsubsection{ICP-OES}

The experimentation and data collection were performed on a Perkin Elmer Avio 200 which was equipped with an S10 autosampler. Freshly prepared aqua regia was used for the digestion of the catalysts, and the solutions were allowed to digest for $12 \mathrm{~h}$ at $120{ }^{\circ} \mathrm{C}$ following the procedure used in MacQueen et al. [19].

\subsubsection{SEM}

SEM was conducted on a Zeiss Gemini 500 Field Emission Scanning Electron Microscope with a Type II Secondary Electron Detector (SE2) and a voltage of $5 \mathrm{keV}$. SEM images of the $\mathrm{CeO}_{2}$ support and the $\mathrm{ReO}_{x}-\mathrm{Pd} / \mathrm{CeO}_{2}$ catalyst are shown in Figure 2 . The $\mathrm{CeO}_{2}$ support was subjected to the same heating treatments and grinding procedure as the $\mathrm{ReO}-\mathrm{Pd} / \mathrm{CeO}_{2}$ catalyst, as described in the catalyst preparation section.

\subsubsection{XRD}

XRD was conducted using a Rigaku MiniFlex II with $\mathrm{Cu} \mathrm{K} \alpha$ source radiation $(\alpha=1.5406 \AA$ ). Each sample was scanned between a $2 \theta$ of $10^{\circ}$ to $80^{\circ}$ at a scanning rate of $2^{\circ} / \mathrm{min}$ and a step size of $0.02^{\circ}$. The resulting diffraction patterns, shown in Figure S3, matched the reference patterns for $\mathrm{CeO}_{2}$ and previously reported $\mathrm{ReO}-\mathrm{Pd} / \mathrm{CeO}_{2}$ catalyst diffraction pattern $[9,19]$.

\subsubsection{TPR}

TPR was conducted on a Micrometrics AutoChem II chemisorption analyzer. The sample was first subjected to a moisture removal step, which ramped from room temperature to $120{ }^{\circ} \mathrm{C}$ in a He environment at $10{ }^{\circ} \mathrm{C} / \mathrm{min}$ and was held at $120{ }^{\circ} \mathrm{C}$ for $1 \mathrm{~h}$. Following the hold, the sample was cooled to $40{ }^{\circ} \mathrm{C}$ at $10{ }^{\circ} \mathrm{C} / \mathrm{min}$ in a He environment. Once $40{ }^{\circ} \mathrm{C}$ was reached, the gas environment was switched from $\mathrm{He}$ to a $10 \% \mathrm{H}_{2}$ in Ar mixture and was held for $30 \mathrm{~min}$. After this hold, the TPR experimentation was conducted by ramping from $40{ }^{\circ} \mathrm{C}$ to $800{ }^{\circ} \mathrm{C}$ at $5{ }^{\circ} \mathrm{C} / \mathrm{min}$ while recording a data point every second. Once the sample reached $800^{\circ} \mathrm{C}$ the detector stopped recording data and gas flow was switched to He to purge the $\mathrm{H}_{2}$ and Ar mixture. The sample was then cooled to $25^{\circ} \mathrm{C}$ at a cooling rate of $20^{\circ} \mathrm{C} / \mathrm{min}$.

\subsubsection{In-Situ Raman}

In-situ Raman spectroscopy was conducted with a Horiba XploRA Plus Raman microscope that utilizes a $30 \mathrm{~mW}$ excitation source, a $638 \mathrm{~nm}$ diode laser, and a Horiba Scientific charge-coupled device detector. The laser was calibrated using a polystyrene standard, and the detector was thermoelectrically cooled to $-50{ }^{\circ} \mathrm{C}$. A Linkam THMS600PS in-situ Raman cell was utilized for the experimentation. An ambient spectrum was first taken, and then the sample was heated to $550{ }^{\circ} \mathrm{C}$ at $50^{\circ} / \mathrm{min}$ while flowing $20 \mathrm{sccm}$ of ultra-high purity $\mathrm{O}_{2}\left(99.9993 \% \mathrm{O}_{2}\right)$ and held at $550{ }^{\circ} \mathrm{C}$ for $30 \mathrm{~min}$. Following the calcination, the cell was purged of $\mathrm{O}_{2}$ with $\mathrm{Ar}$ and then reduced in $20 \mathrm{sccm}$ of a 1:1 volume mixture of $\mathrm{H}_{2}$ and $\mathrm{Ar}$ for $10 \mathrm{~min}$. After the reduction, the cell was again purged with Ar and then exposed to an $\mathrm{O}_{2}$ environment $\left(20 \mathrm{sccm} \mathrm{O}_{2}\right)$ at $550{ }^{\circ} \mathrm{C}$ to reoxidize the sample for $10 \mathrm{~min}$. Following the re-oxidation, the cell was purged with $\mathrm{Ar}$ and then cooled to $100{ }^{\circ} \mathrm{C}$ while flowing $20 \mathrm{sccm}$ of Ar. Spectra were then collected at every $10{ }^{\circ} \mathrm{C}$ from $100{ }^{\circ} \mathrm{C}$ to $180{ }^{\circ} \mathrm{C}$. The resulting spectra from the ambient, calcined, reoxidized, and temperature scans are shown in Figure S5. 


\subsection{Reactor Setup}

A homebuilt $150 \mathrm{~mL}$ high-pressure batch reactor that was machined from 316 stainless steel that was previously described in MacQueen et al. [9] was utilized for the kinetic measurements in this study. This reactor system allows for on-stream samples to be taken so that kinetic data can be elucidated from a single reaction at multiple time points. The reaction solution within the reactor was mixed using a magnetic stir bar and a stir plate. The reactor was heated via an oil bath and was coupled to a PID controller to maintain the desired temperature throughout the reaction.

\subsection{Kinetic Measurements}

The xylitol S-HDO reactions were conducted to determine the general kinetics of the reaction, including the activation energy, reaction order, and any mass transfer limitations. For each reaction, the reactor was loaded with the proper amount of catalyst, xylitol, and solvent (1,4-dioxane) along with a magnetic stir bar. The reactor was then sealed with an $\mathrm{O}$-ring, and the reactor was tightened until it was pressure tight. The reactor was then pressure checked and flushed of any air with helium. Following the purge of the helium, the reactor was then heated to the desired temperature using the PID controller and oil bath. Once the desired temperature was reached, the reactor was kept at this temperature for at least $30 \mathrm{~min}$ to ensure the reactor temperature was stable. Once stable, the hydrogen was added to the reactor, and the line to the tank was left open to ensure the reactor maintained 10 bar of pressure. Once the hydrogen was added, the reaction time was started, and the first sample was taken to ensure that no S-HDO or other reactions occurred during the temperature ramping of the reaction solution and reactor. Samples were taken every $30 \mathrm{~min}$ of the reactions for $4 \mathrm{~h}$ or until the volume of the reaction solution was too low to sample to provide an accurate assessment of the reaction over time.

The reaction samples were analyzed with Gas Chromatography (GC) to determine the concentration of xylitol, 1,2,5-pentanetriol, 1,2-dideoxypentitol, 3-pentanol, 1-pentanol, and 1,2-pentanediol. Each component was calibrated by making an 8-point calibration curve with known concentration standards. Over the reaction times and temperatures utilized for this study, 3-pentanol, 1-pentanol, and 1,2-pentanediol were not seen in significant concentration since only one S-HDO was occurring. The GC system utilized a Shimadzu GC 2010 Plus along with an AOC-5000 autoinjector. Within the GC an RTX-1701 column was used, and the system utilized a Flame Ionization Detector (FID). The reaction samples were diluted by a factor of $\frac{125}{3}\left(\frac{\text { solvent }}{\text { reactant }}\right)$ times their original volume in methanol to ensure that the FID would not saturate. $1 \mu \mathrm{L}$ of the GC samples were injected into the system per sample using a split ratio of $1: 10$ with a column flow of $2.5 \mathrm{~mL} / \mathrm{min}$ and a total flow of $30.5 \mathrm{~mL} / \mathrm{min}$. The injection needle was washed three times in acetone and then three times in methanol between each injection. The GC oven was programmed to start at $40{ }^{\circ} \mathrm{C}$ and hold for $3 \mathrm{~min}$, followed by a heating ramp of $10^{\circ} \mathrm{C} / \mathrm{min}$ to $260^{\circ} \mathrm{C}$. Once the oven reached $260^{\circ} \mathrm{C}$ it was held for $20 \mathrm{~min}$. After the program was finished, the column was then cooled to $40{ }^{\circ} \mathrm{C}$ in preparation for the next sample.

Reaction order determination and activation energy elucidation reactions were conducted at temperatures between 120 to $170{ }^{\circ} \mathrm{C}$. Each reaction utilized $0.60 \mathrm{~g}$ of $\mathrm{ReO}_{\mathrm{x}}$ $\mathrm{Pd} / \mathrm{CeO}_{2}$ catalyst, $2.0 \mathrm{~g}$ of xylitol, and $50 \mathrm{~mL}$ of solvent (1,4-dioxane). For mass transfer evaluations with respect to xylitol concentration, the reaction temperature was fixed at $160{ }^{\circ} \mathrm{C}$, and the amount of $\mathrm{ReO}_{\mathrm{x}}-\mathrm{Pd} / \mathrm{CeO}_{2}$ catalyst and xylitol were varied while fixing the solvent volume at $50 \mathrm{~mL}$ and maintaining a 0.3:1.0 wt. ratio of catalyst to xylitol, which was previously reported to be optimal [19].

To probe the effects of mixing within the reactor and any associated external mass transfer limitations in the reaction, the stirring rate was varied from between 150 and $700 \mathrm{rpm}$ while fixing the reaction temperature, catalyst, xylitol, and solvent amounts at $160{ }^{\circ} \mathrm{C}, 0.60 \mathrm{~g}, 2.0 \mathrm{~g}$, and $50 \mathrm{~mL}$ respectively between reactions. The Weisz-Prater criterion was also calculated to evaluate internal mass transfer. The effect of reactant concentration experiments was conducted at $160{ }^{\circ} \mathrm{C}$ and varied xylitol concentration from $0.5-8 \mathrm{~g}$ while 
keeping the solvent concentration $(50 \mathrm{~mL})$, and catalyst to reactant ratio constant $(0.30 \mathrm{~g}$ catalyst: $1 \mathrm{~g}$ xylitol). All reactions in this study above were conducted at $10 \mathrm{bar} \mathrm{H}_{2}$.

\title{
4. Conclusions
}

In conclusion, we conducted the first comprehensive kinetics study of xylitol simultaneous hydrodeoxygenation. The S-HDO of xylitol over $\mathrm{ReO}_{x}-\mathrm{Pd} / \mathrm{CeO}_{2}$ was determined to be a zero-order reaction. The Arrhenius activation energy of the reaction was determined to be $48.7 \pm 10.5 \mathrm{~kJ} / \mathrm{mol}$. A sub-Arrhenius relation was found from $120-170{ }^{\circ} \mathrm{C}$ in which activation energy was temperature dependent and ranged from $10.2-51.8 \mathrm{~kJ} / \mathrm{mol}$. The Weisz-Prater criterion was evaluated, and it was determined that no internal diffusion limitations were present since the criterion was much less than 1 for both xylitol and hydrogen. There were no external mass transfer limitations found when varying the stirring rate over a range of $150-700 \mathrm{rpm}$. The di-oxo $(\mathrm{O}=\mathrm{Re}=\mathrm{O})$ species of $\mathrm{ReO}_{\mathrm{x}}$ was found to increase in concentration as temperature is increased in Raman spectroscopy. The catalyst synthesis parameters and environment cause a small agglomeration of the $\mathrm{CeO}_{2}$ particles and increases the average particle size from 3.00 to $4.30 \mu \mathrm{m}$.

Supplementary Materials: The following are available online at https://www.mdpi.com/2073-434 4/11/1/108/s1, Figure S1: XRF X-Y position (in cm) composition contour of ReOx-Pd/CeO2 catalyst (a) Re contour, (b) Pd contour, Figure S2: SEM of $\mathrm{CeO} 2$ support and $2 \mathrm{wt} \% \mathrm{ReOx}-\mathrm{Pd} / \mathrm{CeO} 2$ catalyst. (a) $\mathrm{CeO} 2134 \times$ magnification (b) $\mathrm{ReOx}-\mathrm{Pd} / \mathrm{CeO} 2150 \times$ magnification (c) $\mathrm{CeO} 23540 \times$ magnification (d) $\mathrm{ReOx}-\mathrm{Pd} / \mathrm{CeO} 24400 \times$ magnification, Figure S3: XRD patterns of $2 \mathrm{wt} \% \mathrm{ReOx}-\mathrm{Pd} / \mathrm{CeO} 2$ catalysts at a scanning rate of $2^{\circ} / \mathrm{min}$ with a step size of $0.02^{\circ}$, Figure S4: Representative H2 TPR profile of $2 \mathrm{wt} \% \mathrm{ReOx}-\mathrm{Pd} / \mathrm{CeO} 2$ catalyst, Figure S5. In-situ Raman spectra of $2 \mathrm{wt} \% \mathrm{ReOx}-\mathrm{Pd} / \mathrm{CeO} 2$ catalyst.

Author Contributions: Conceptualization, B.M. and J.L.; methodology, B.M. and J.L.; validation, B.M., M.R., and B.S.C.; formal analysis, B.M.; investigation, B.M., M.R., and B.S.C.; resources, B.M.; data curation, B.M.; writing-original draft preparation, B.M.; writing—review and editing, B.M., M.R., A.H., Y.J.P.-T., and J.L.; visualization, B.M., and M.R.; supervision, J.L.; project administration, J.L.; funding acquisition, A.H., Y.J.P.-T., and J.L. All authors have read and agreed to the published version of the manuscript.

Funding: This research was funded by the National Science Foundation grant number OIA-1632824 and DGE-1250052.

Data Availability Statement: The data presented in this study are available on request from the corresponding author.

Acknowledgments: We gratefully acknowledge financial support from the National Science Foundation (OIA-1632824 and DGE-1250052). This work was also supported by the South Carolina Smart State Center for Strategic Approaches to the Generation of Electricity (SAGE). We would like to acknowledge Benjamin Ruiz-Yi for scientific discussion regarding the Raman spectroscopy.

Conflicts of Interest: The authors declare no conflict of interest.

\begin{abstract}
Abbreviations
Simultaneous Hydrodeoxygenation (S-HDO), Deoxydehydration (DODH), Density Functional Theory (DFT), X-ray Fluorescence Spectroscopy (XRF), X-ray Diffraction (XRD), Temperature Programmed Reduction (TPR), Scanning Electron Microscopy (SEM), Inductively Coupled PlasmaOptical Emission Spectrometry (ICP-OES), grams of catalyst ( $\left.\mathrm{g}_{\text {cat }}\right)$, Confidence Interval (CI), Ultra High Purity (UHP), Gas Chromatography (GC), Flame Ionization Detector (FID).
\end{abstract}

\section{References}

1. Alonso, D.M.; Wettstein, S.G.; Dumesic, J.A. Bimetallic Catalysts for Upgrading of Biomass to Fuels and Chemicals. Chem. Soc. Rev. 2012, 41, 8075-8098. [CrossRef]

2. Melin, K.; Hurme, M. Evaluation of Lignocellulosic Biomass Upgrading Routes to Fuels and Chemicals. Cellul. Chem. Technol. 2010, 44, 117-137. 
3. Luterbacher, J.S.; Martin Alonso, D.; Dumesic, J.A. Targeted Chemical Upgrading of Lignocellulosic Biomass to Platform Molecules. Green Chem. 2014, 16, 4816-4838. [CrossRef]

4. Stalpaert, M.; De Vos, D. Stabilizing Effect of Bulky $\beta$-Diketones on Homogeneous Mo Catalysts for Deoxydehydration. ACS Sustain. Chem. Eng. 2018, 6, 12197-12204. [CrossRef]

5. Venkateswar Rao, L.; Goli, J.K.; Gentela, J.; Koti, S. Bioconversion of Lignocellulosic Biomass to Xylitol: An Overview. Bioresour. Technol. 2016, 213, 299-310. [CrossRef] [PubMed]

6. Sena, L.M.F.; Morais, C.G.; Lopes, M.R.; Santos, R.O.; Uetanabaro, A.P.T.; Morais, P.B.; Vital, M.J.S.; de Morais, M.A.; Lachance, M.A.; Rosa, C.A. D-Xylose Fermentation, Xylitol Production and Xylanase Activities by Seven New Species of Sugiyamaella. Antonie van Leeuwenhoek 2017, 110, 53-67. [CrossRef]

7. Rao, R.S.; Prakasham, R.S.; Prasad, K.K.; Rajesham, S.; Sarma, P.N.; Rao, L.V. Xylitol Production by Candida Sp.: Parameter Optimization Using Taguchi Approach. Process Biochem. 2004, 39, 951-956. [CrossRef]

8. Granström, T.B.; Izumori, K.; Leisola, M. A Rare Sugar Xylitol. Part II: Biotechnological Production and Future Applications of Xylitol. Appl. Microbiol. Biotechnol. 2007, 74, 273-276. [CrossRef]

9. MacQueen, B.; Barrow, E.; Rivera Castro, G.; Pagan-Torres, Y.; Heyden, A.; Lauterbach, J. Optimum Reaction Conditions for 1,4-Anhydroerythritol and Xylitol Hydrodeoxygenation over a ReOx-Pd/Ceo2 Catalyst via Design of Experiments. Ind. Eng. Chem. Res. 2019, 58, 8681-8689. [CrossRef]

10. Ota, N.; Tamura, M.; Nakagawa, Y.; Okumura, K.; Tomishige, K. Hydrodeoxygenation of Vicinal OH Groups over Heterogeneous Rhenium Catalyst Promoted by Palladium and Ceria Support. Angew. Chem. Int. Ed. 2015, 54, 1897-1900. [CrossRef]

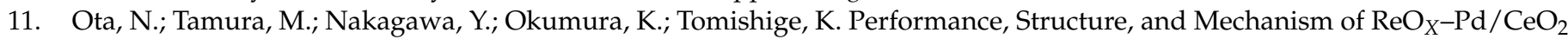
Catalyst for Simultaneous Removal of Vicinal OH Groups with $\mathrm{H}_{2}$. ACS Catal. 2016, 6, 3213-3226. [CrossRef]

12. Yamaguchi, A.; Hiyoshi, N.; Sato, O.; Bando, K.K.; Shirai, M. Enhancement of Cyclic Ether Formation from Polyalcohol Compounds in High Temperature Liquid Water by High Pressure Carbon Dioxide. Green Chem. 2009, 11, 48-52. [CrossRef]

13. Yamaguchi, A.; Hiyoshi, N.; Sato, O.; Shirai, M. Sorbitol Dehydration in High Temperature Liquid Water. Green Chem. 2011, 13, 873-881. [CrossRef]

14. Tamura, M.; Yuasa, N.; Cao, J.; Nakagawa, Y.; Tomishige, K. Transformation of Sugars into Chiral Polyols over a Heterogeneous Catalyst. Angew. Chem. Int. Ed. 2018, 57, 8058-8062. [CrossRef] [PubMed]

15. Xi, Y.; Yang, W.; Ammal, S.C.; Lauterbach, J.; Pagan-Torres, Y.; Heyden, A. Mechanistic Study of the Ceria Supported, Re-Catalyzed Deoxydehydration of Vicinal OH Groups. Catal. Sci. Technol. 2018, 8, 5740-5752. [CrossRef]

16. Wu, D.; Zhang, Y.; Su, H. Mechanistic Study on Oxorhenium-Catalyzed Deoxydehydration and Allylic Alcohol Isomerization. Chem. Asian J. 2016, 11, 1565-1571. [CrossRef]

17. Cao, J.; Tamura, M.; Hosaka, R.; Nakayama, A.; Hasegawa, J.; Nakagawa, Y.; Tomishige, K. Mechanistic Study on Deoxydehydration and Hydrogenation of Mechanistic Study on Deoxydehydration and Hydrogenation of Me- Thyl Glycosides to Dideoxy Sugars over $\mathrm{ReO}_{X}-\mathrm{Pd} / \mathrm{CeO}_{2}$ Catalyst. ACS Catal. 2020, 10, 12040-12051. [CrossRef]

18. Xi, Y.; Lauterbach, J.; Pagan-Torres, Y.; Heyden, A. Deoxydehydration of 1,4-Anhydroerythritol over Anatase TiO2(101)-Supported ReOxand MoOx. Catal. Sci. Technol. 2020, 10, 3731-3738. [CrossRef]

19. MacQueen, B.; Ruiz-Yi, B.; Royko, M.; Heyden, A.; Pagan-Torres, Y.J.; Williams, C.; Lauterbach, J. In-situ Oxygen Isotopic Exchange Vibrational Spectroscopy of Rhenium Oxide Surface Structures on Cerium Oxide. J. Phys. Chem. C 2020, 124, 7174-7181. [CrossRef]

20. Shirbhate, S.; Yadav, A.K.; Acharya, S. Investigation of in-situ Oxygen Vacancies Dissociation Mechanism and Associated Atomic Scale Reshuffling during Oxy-Ion Migration in Nanostructured Co-Doped Ceria. Solid State Ion. 2020, 345, 115157. [CrossRef]

21. Cordatos, H.; Bunluesin, T.; Stubenrauch, J.; Vohs, J.M.; Gorte, R.J. Effect of Ceria Structure on Oxygen Migration for Rh/Ceria Catalysts. J. Phys. Chem. 1996, 100, 785-789. [CrossRef]

22. Varalda, J.; Dartora, C.A.; De Camargo, P.C.; De Oliveira, A.J.A.; Mosca, D.H. Oxygen Diffusion and Vacancy Migration Thermally-Activated Govern High-Temperature Magnetism in Ceria. Sci. Rep. 2019, 9, 1-9. [CrossRef] [PubMed]

23. Balducci, G.; Islam, M.S.; Kaspar, J.; Fornasiero, P.; Graziani, M. Bulk Reduction Oxygen Migration in the Ceria-Based Oxides. Chem. Mater. 2000, 12, 677-681. [CrossRef]

24. Nolan, M.; Fearon, J.E.; Watson, G.W. Oxygen Vacancy Formation and Migration in Ceria. Solid State Ion. 2006, 177, 3069-3074. [CrossRef]

25. Silva, V.H.C.; Aquilanti, V.; De Oliveira, H.C.B.; Mundim, K.C. Uniform Description of Non-Arrhenius Temperature Dependence of Reaction Rates, and a Heuristic Criterion for Quantum Tunneling vs. Classical Non-Extensive Distribution. Chem. Phys. Lett. 2013, 590, 201-207. [CrossRef]

26. Gregório, A.P.H.; Borsato, D.; Moreira, I.; Silva, E.T.; Romagnoli, É.S.; Spacino, K.R. Apparent Activation Energy and Relative Protection Factor of Natural Antioxidants in Mixture with Biodiesel. Biofuels 2019, 10, 607-614. [CrossRef]

27. Nishiyama, M.; Kleijn, S.; Aquilanti, V.; Kasai, T. Temperature Dependence of Respiration Rates of Leaves, 18O-Experiments and Super-Arrhenius Kinetics. Chem. Phys. Lett. 2009, 482, 325-329. [CrossRef]

28. Truhlar, D.G.; Kohen, A. Convex Arrhenius Plots and Their Interpretation. Proc. Natl. Acad. Sci. USA 2001, 98, 848-851. [CrossRef]

29. Coutinho, N.D.; Silva, V.H.C.; De Oliveira, H.C.B.; Camargo, A.J.; Mundim, K.C.; Aquilanti, V. Stereodynamical Origin of Anti-Arrhenius Kinetics: Negative Activation Energy and Roaming for a Four-Atom Reaction. J. Phys. Chem. Lett. 2015, 6, 1553-1558. [CrossRef] 
30. Coutinho, N.D.; Sanches-Neto, F.O.; Carvalho-Silva, V.H.; de Oliveira, H.C.B.; Ribeiro, L.A.; Aquilanti, V. Kinetics of the $\mathrm{OH}+\mathrm{HCl} \rightarrow \mathrm{H} 2 \mathrm{O}+\mathrm{Cl}$ Reaction: Rate Determining Roles of Stereodynamics and Roaming and of Quantum Tunneling. J. Comput. Chem. 2018, 39, 2508-2516. [CrossRef]

31. Berglin, T.; Schöön, N.H. Selectivity Aspects of the Hydrogenation Stage of the Anthraquinone Process for Hydrogen Peroxide Production. Ind. Eng. Chem. Process Des. Dev. 1983, 22, 150-153. [CrossRef]

32. Santacesaria, E.; Di Serio, M.; Velotti, R.; Leone, U. Kinetics, Mass Transfer, and Palladium Catalyst Deactivation in the Hydrogenation Step of the Hydrogen Peroxide Synthesis via Anthraquinone. Ind. Eng. Chem. Res. 1994, 33, 277-284. [CrossRef]

33. Lari, G.M.; Grçninger, O.G.; Li, Q.; Mondelli, C.; Javier, P.Ø. Catalyst and Process Design for the Continuous Manufacture of Rare Sugar Alcohols by Epimerization-Hydrogenation of Aldoses. ChemSusChem 2016, 9, 3407-3418. [CrossRef]

34. Ruppert, A.M.; Weinberg, K.; Palkovits, R. Hydrogenolysis Goes Bio: From Carbohydrates and Sugar Alcohols to Platform Chemicals. Angew. Chem. Int. Ed. 2012, 51, 2564-2601. [CrossRef] [PubMed]

35. Vilcocq, L.; Cabiac, A.; Especel, C.; Guillon, E.; Duprez, D. Transformation of Sorbitol to Biofuels by Heterogeneous Catalysis: Chemical and Industrial Considerations. Oil Gas Sci. Technol. Rev. d'IFP Energ. Nouv. 2013, 68, 841-860. [CrossRef]

36. Peng, B.; Zhao, C.; Mejía-centeno, I.; Fuentes, G.A.; Jentys, A.; Lercher, J.A. Comparison of Kinetics and Reaction Pathways for Hydrodeoxygenation of C3 Alcohols on Pt/Al2O3. Catal. Today 2012, 183, 3-9. [CrossRef]

37. Sievers, C.; Scott, S.L.; Noda, Y.; Qi, L.; Albuquerque, E.M.; Rioux, R.M. Phenomena Affecting Catalytic Reactions at solid-Liquid Interfaces. ACS Catal. 2016, 6, 8286-8307. [CrossRef]

38. Harju, H.; Pipitone, G.; Lefferts, L. Influence of the Catalyst Particle Size on the Aqueous Phase Reforming of N-Butanol Over $\mathrm{Rh} / \mathrm{ZrO} 2$. Front. Chem. 2020, 8, 17. [CrossRef]

39. Fu, J.; Lu, X.; Savage, P.E. Catalytic Hydrothermal Deoxygenation of Palmitic Acid. Energy Environ. Sci. 2010, 13, 253. [CrossRef]

40. Mukherjee, S.; Vannice, M.A. Solvent Effects in Liquid-Phase Reactions. I. Activity and Selectivity during Citral Hydrogenation on $\mathrm{Pt} / \mathrm{SiO}_{2}$ and Evaluation of Mass Transfer Effects. J. Catal. 2006, 243, 108-130. [CrossRef]

41. Brunner, E. Solubility of Hydrogen in 10 Organic Solvents at 298.15, 323.15, and 373.15 K. J. Chem. Eng. Data 1985, 30, 269-273. [CrossRef] 